\title{
Manufacture of Precheese Powder by Use of Low-temperature Renneting Made from Raw Milk Using Spray Dryer
}

\author{
Shuo-Feng An, Jing-Zhu Piao, and Oun-Ki Chang ${ }^{1 *}$ \\ Department of Animal Resources and Biotechnology, Chonbuk National University, Jeonju 561-756, Korea \\ ${ }^{1}$ URAFPA, Equipe Protéolyse-Biofonctionalité des Protéines et Peptides, Nancy-Université, \\ Vandoeuvre-lès-Nancy 54506, France
}

\begin{abstract}
Among the food constituents, proteins differ in coagulation properties as compared to other constituents in food system. Especially milk protein coagulate through different pathways thus this coagulability can be used for manufacture of various dairy products or as a determinant of dairy product analysis. These milk coagulation methods include organic solvent, isoelectric point, trichloroacetic acid, Ca-sensitive casein, heavy metal ion and rennet coagulation. The coagulation experiment was performed using above parameters at $0^{\circ} \mathrm{C}$ and $25^{\circ} \mathrm{C}$ to find the dehydration conditions before coagulating for precheese powder making. After different chemical treatments, there was no coagulation at $0^{\circ} \mathrm{C}$ rather at $25^{\circ} \mathrm{C}$ whatever the mode of coagulation methods was. The appearance of precipitate with coagulation methods was quite different from above mentioned methods of coagulation illustrated by scanning electron microscope. These powders were used for fabrication of camembert cheese by renneting coagulation at $0^{\circ} \mathrm{C}$, showing the possibility of cheese materials and of food additives for fabrication of products.
\end{abstract}

Key words: low-temperature renneting, precheese powder, spray drying, coagulation, casein micelle, scanning electron microscopy

\section{Introduction}

Generally, coagulation of protein by enzymes is very important in the milk and blood and its mechanism is very complex and not yet completely cleared but still vast possibilities to use them for development of new dairy products. We know that there are so many types of coagulation or precipitation in food which takes a place through various principles and pathways (Lee, 1981).

Caseins $(\alpha, \beta$, and $\kappa)$ as a major protein in milk exist in the form of stable dispersion known as micelle due to $\mathrm{Ca}$ phosphate interaction between submicelles in milk (Ausar et al., 2001). The hydrophilic phosphate group (hairs of $\kappa$-casein molecule) of $\mathrm{C}$-terminal end of $\kappa$-casein protrudes from the micelle surface to protect micelle (Holt, 1992; Holt and Horne, 1996).

These caseins can coagulate by diverse coagulation factors/parameters such as rennet, solvent, heating and acid

*Corresponding author: Oun-Ki Chang, UR AFPA - équipe PB2P, Faculté des Sciences et Techniques, Nancy-Université, B.P. 239, 54506 Vandoeuvre-lès-Nancy Cedex, France. Tel: 33 3836842 72, Fax: 333836842 74, E-mail: ounki.chang@, ensaia.inpl-nancy.fr by results of strong hydrophobic interaction between micelle due to steric stabilization layer damage or collapses (Walstra and Jenness, 1984). The most of flocculation are the heat coagulation of whey proteins (Rašiæ and Kurmann, 1978) and the other is the casein precipitation in the presence of $\mathrm{Ca}^{2+}$ at low $\mathrm{pH}$ such as yogurt and coprecipitate (Robinson, 1986). Among the different coagulation factors, the flocculation by dehydration of organic solvents such as ethanol and acetone can be altered the micelle stability. The freshness of raw milk called platform test is evaluated by $35 \%$ of ethanol (Ministère de l'Agriculture, 1973).

The isoelectric coagulation (precipitation) is also used at $\mathrm{pH} 4.6$ for caseins. The precipitate can be neutralized with bases at $\mathrm{pH} 7.0$ such as $\mathrm{NaOH}, \mathrm{KOH}, \mathrm{Mg}(\mathrm{OH})_{2}$, $\mathrm{Ca}(\mathrm{OH})_{2}$ and $\mathrm{Al}_{2}(\mathrm{OH})_{3}$ which make Na-caseinate, $\mathrm{K}$ caseinate, Mg-caseinate, Ca-caseinate and Al-caseinate, respectively (Robinson, 1986). On the other hand, the caseins of cheese can also be coagulated in presence of high concentration of $\mathrm{CaCl}_{2}$ which is called calcium sensitive caseins to evaluate the ripening degree (Noomen, 1977).

Trichloroacetic acid (TCA) precipitation is the best well 
known method to separate the protein or non protein which is used widely for the determination of ripening degree in the different cheeses (Fritsch et al., 1992; Ko et al., 2002; Schlesser et al., 1992).

The caseins and whey proteins in the milk can also be precipitated by deproteination in the presence of heavy metal ions such as $\mathrm{Ag}, \mathrm{Cu}, \mathrm{Pb}$ and $\mathrm{W}$ due to disrupt of salt bridges in proteins by forming ionic bonds with negatively charged groups. The most of proteins including enzyme can also be precipitated reversible by salting out using $\mathrm{Na}_{2} \mathrm{SO}_{4}, \mathrm{MgSO}_{4}$ and $\left(\mathrm{NH}_{4}\right)_{2} \mathrm{SO}_{4}$ for purification of enzyme (Korean Biochemistry Society, 1997).

In the coagulation of milk, the most important method is the enzymatic coagulation. The rennet also known as chymosin (E.C. 3, 4, 23, 4) is used in cheese technology. It is well known that there are three stages of milk coagulation. The first stage is proteolysis by rennet which hydrolyzes specifically between $\mathrm{Phe}_{105}-\mathrm{Met}_{106}$ of $\mathrm{K}$ casein and is flocculated by skeletal formation above $20^{\circ} \mathrm{C}$ (Ko et al., 2002).

Rennet coagulation of bovine milk is one of the most widely known milk process and is a fundamental in cheese technology. The coagulation of milk by rennet is generally considered to occur in this stage (Alais, 1974; de Kruif and Holt, 2003; Lucey and Singh, 2003).

As mentioned above, the first stage of milk coagulation by rennet is the cleavage of $\kappa$-casein which releases the soluble caseino glycomacro peptide (GMP, 106-169 bond of $\kappa$-casein) into the whey, leaving the para-K-casein (1105 bond of $\kappa$-casein) attached to the casein micelle and becomes Ca-paracaseinate cheese later (Horne and Banks, 2004; O'Connell and Fox, 2000).

The hydration state of casein micelle thus changes due to the loss of hydrophilic phosphate group of $\kappa$-casein on surface and radius of casein micelle shrink (de Kruif and Holt, 2003).

This stage is a only specific proteolysis on the hydrophilic C-terminal region of $\mathrm{K}$-casein on micellar casein surface, but flocculation is not visible at this stage. The first stage depends upon time-temperature for rennet action to casein. The second stage of coagulation is nonenzymatic aggregation of ca-paracaseinate but not enzymatically. Three dimensional gel network change of its surface led to a mass of curd by syneresis in cheese at temperature above $20^{\circ} \mathrm{C}$ due to the increased hydrophobicity (Alais, 1974). It is very important to note that second phase flocculation does not occurr below $20^{\circ} \mathrm{C}$. There is a patent called Paracurd or SH-13 for continuous cheese fabrication (Alais, 1974). The method uses low temperature renneting, the concentrated raw milk was renneted below $20^{\circ} \mathrm{C}$ during long time to develop first stage of coagulation by reason of several advantages, for example the decrease of fabrication time, the rapid ripening, the improvement of $\mathrm{Ca}, \mathrm{P}$ content and the increase of whey soluble proteins $(5-12 \%)$. The formation of curd is possible by momentarily adding and mixing 3 volume of $95^{\circ} \mathrm{C}$ water in the renneted concentrated raw milk.

Up to now, many research have been worked about the high temperature or high pressure of coagulation instead of low temperature renneting (Alais, 1974; Bansal et al., 2008).

Therefore, the objective of this study is to find the dehydration conditions of the renneted raw milk at low temperature prior to enter into second stage (flocculation). This method is useful for making precheese powder to apply in the various food industries as food additives and raw cheese materials.

\section{Materials and Methods}

\section{Materials}

Raw milk sample was collected from 16 healthy milking cows at Chonbuk National University farm on 20th May 2008.

\section{Methods}

\section{Chemical coagulation treatments}

Various chemical coagulation treatments such as organic solvent, pHi, trichloroacetic acid (TCA), calcium, heavy metal ions and rennet with various biochemical principles to raw milk at $0^{\circ} \mathrm{C}$ and $25^{\circ} \mathrm{C}$ were used to know the effect of low temperature coagulation. The flocculate transmittances were measured as previously described method (Bansal et al., 2007) using spectrophotometer (Optizen 2120 UV, Mecasys, Korea) The samples after precipitation treatment were diluted 100 times in $0.2 \%$ EDTA, pH 12 (Manso et al., 2005). These solutions were centrifuged at each temperature $(580 \mathrm{~g}, 10 \mathrm{~min})$ to show the appearance of coagulation.

- Precipitation by ethanol

Ten mililiters of fresh raw milk was added to equal volume of ethanol and agitated at $0^{\circ} \mathrm{C}$ and $25^{\circ} \mathrm{C}$, respectively.

- Isoelectric point precipitation (pHi 4.6) by acetate

Two $\mathrm{M}$ acetate buffer ( $\mathrm{pH}$ 4.6) was added to the equal 
volume of milk and shaked using vortex mixer at $0^{\circ} \mathrm{C}$ and $25^{\circ} \mathrm{C}$ respectively.

\section{- TCA precipitation}

Twenty-four percent(w/v) of TCA was added to the equal volume of raw milk. The sample was agitated at $0^{\circ} \mathrm{C}$ and $25^{\circ} \mathrm{C}$ respectively.

\section{- Precipitation by cupric sulphate}

One mililiter of $10 \%(\mathrm{w} / \mathrm{v}) \mathrm{CuSO}_{4}$ was added in $50 \mathrm{~mL}$ of raw milk at $0^{\circ} \mathrm{C}$ and $25^{\circ} \mathrm{C}$ respectively.

- Precipitation of calcium chloride in cheese

$1 \mathrm{M} \mathrm{CaCl}_{2}$ was added to $50 \mathrm{~mL}$ of cheese suspension $\left(5 \%\right.$ cheese in $10 \%$ of $\mathrm{Na}$-citrate) at $0^{\circ} \mathrm{C}$ and $25^{\circ} \mathrm{C}$ respectively.

\section{- Rennet coagulation}

Ten mililiters of raw milk, $0.01 \%(\mathrm{v} / \mathrm{v})$ of rennet (Chr. Hansen, Denmark) and $0.001 \%(\mathrm{w} / \mathrm{v})$ of $\mathrm{CaCl}_{2}$ was incubated at $0^{\circ} \mathrm{C}$ and $25^{\circ} \mathrm{C}$ for $20 \mathrm{~min}$, respectively.

- Influence of $\mathrm{Ca}^{2+}$ and $\mathrm{Na}^{+}$on coagulation at low temperature

To confirm the influence of $\mathrm{CaCl}_{2}$ and $\mathrm{NaCl}$ addition for coagulation at low temperature according to time, the coagulation was observed at $4^{\circ} \mathrm{C}$ by visual clotting time. All the treated samples $(0,1 \%)$ were added in 6 tubes of raw milk and then these tubes were divided 12 tubes. Finally, $1 \mathrm{M} \mathrm{CaCl}_{2}$ and $1 \mathrm{M} \mathrm{NaCl}$ were added, respectively.

\section{Scanning electron microscopy (SEM)}

SEM was performed as previously discribed method (Chang et al., 2006). The precipitated sample solutions were diluted to 500 times with phosphate buffer ( $\mathrm{pH} 7.2$ ) and one drop of diluted solution was placed on slide to dry at room temperature. The dried sample was dehydrated by use of amyl acetate and coated in Gold Coater (Cressington 108, Japan). The surface of precipitate was observed on scanning electron microscope (JSM-6400 and ISI 130, JEOL Co., Japan) at $5 \mathrm{kV}$ acceleration voltage.

\section{Spray drying conditions to fabricate the precheese powder}

Among diverse coagulations, the rennet coagulation was used for the production of precheese powder. To
Table 1. Proposed dehydration conditions of spray drying (patent of Hanboul Foodcheepia Co. 2005)

\begin{tabular}{ll}
\hline \hline $\begin{array}{l}\text { Temperature of milk } \\
\text { (concentration milk) }\end{array}$ & \multicolumn{1}{c}{$0{ }^{\circ} \mathrm{C}$} \\
\hline Temperature of inlet & $105^{\circ} \mathrm{C}$ to $165^{\circ} \mathrm{C}$ \\
Temperature of outlet & $75^{\circ} \mathrm{C}$ to $120^{\circ} \mathrm{C}$ \\
Spray drying pressure & 8 to $10 \mathrm{kpa}$ \\
Dry air volume & 0.4 to $0.42 \mathrm{~m}^{3} / \mathrm{min}$ \\
\hline
\end{tabular}

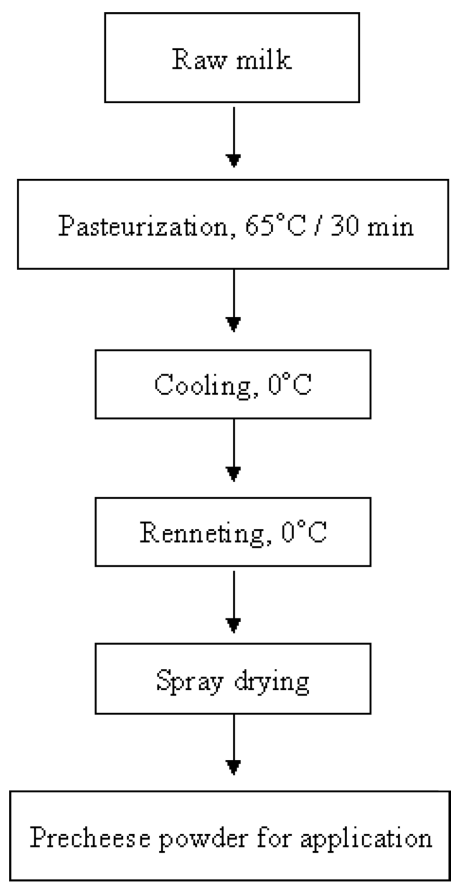

Fig. 1. Schematic representation of the precheese powder making process using low temperature renneting.

obtain the precheese powder, the raw milk was processed as shown in Fig. 1. Renneted milk at $0^{\circ} \mathrm{C}$ before going to coagulation in second stage was powdered by spray drying. The conditions of spray drying were presented in Table 1. We used various drying conditions of spray drier as the temperature from 105 to $165^{\circ} \mathrm{C}$ (Table 1).

\section{Experimental fabrication of Camembert cheese}

After retrieve of this powder in the Fig. 1, the powder $(60 \%)$ was solubilized in water at $5^{\circ} \mathrm{C}$ with normal commercial starter FD-DVS culture FLORA-DANICA and FDVS culture CHN or FLORA DANICA and Penicillium camemberti (Chr. Hansen, Denmark) for Camembert cheese without syneresis. It was ripened at $22^{\circ} \mathrm{C}$ with 95\% humidity during $25 \mathrm{~d}$ which was modified as a previously method (Boutrou et al., 1999; Molimard et al., 1995). 


\section{Results and Discussion}

\section{Coagulation (Precipitation) techniques by chemical treatment factors}

It has well known that casein micelles are formed by thousands of submicelles in the dispersed colloidal form (Schmidt, 1982; Walstra, 1999). The colloidal calcium phosphate (CCP) acts as a cement between submicelles that form the casein micelles. The binding between the submicelles may be covalent or electrostatic. Submicelles rich in $\kappa$-casein occupy a surface position, whereas hydrophobic groups are buried in the interior. The resulting hairy layer of $\mathrm{K}$-casein acts to prohibit further aggregation of submicelles by hydrophobic and negative charge steric repulsion. The casein micelles are not static; there are three dynamic equilibriums between the submicelles and its surroundings such as the free casein molecules and susbmicelles, 2) the free submicelles and micelles, and 3) the dissolved colloidal calcium and phosphate. (Holt and Horne, 1996; Horne, 1998, 2002; Walstra, 1999).

Various parameters are considered for casein micelle stability in milk. These parameters have role in $\mathrm{Ca}^{2+}, \mathrm{H}-$ bonding, disulphide bonds, hydrophobic interactions, electrostatic interactions, van der walls forces, steric stabilization, salts, $\mathrm{pH}$, temperature, heat treatment and dehydration in milk. The coagulation of milk depends on interactions of these parameters by diverse chemical precipitation factors (Brinkhuis and Payens, 1984; Dalgleish, 1983; Daviau et al., 2000; Mehaia and Cheryan, 1983; Nájera et al., 2003; Walstra and Jenness, 1984).

Table 2 represents temperature effects on precipitability according to different treatment methods. The coagulation experiments at $25^{\circ} \mathrm{C}$ as a positive control were applied to verify the observation of coagulation comparing to $0^{\circ} \mathrm{C}$. All samples which were treated by different coagulation factors at low temperature did not coagulate even though these have quite different coagulation mechanism from each other.

The precipitation samples had lower transmittance at $0^{\circ} \mathrm{C}(0.555$ to 0.720$)$ than $25^{\circ} \mathrm{C}(0.665$ to 1.410$)$. On the other hand, the raw milk transmittance as a control was 0.580 (data not shown) showing the possibility that the coagulation at $0^{\circ} \mathrm{C}$ does not occur. Even though the transmittance values at 0 and $25^{\circ} \mathrm{C}$ in heavy metal ions, rennet and $\mathrm{pHi}$ coagulation parameters are similar, it is very clear that there is no coagulation in all treatments at $0^{\circ} \mathrm{C}$ (pictures in Table 2). The reason that the higher transmittance at $25^{\circ} \mathrm{C}$ than at $0^{\circ} \mathrm{C}$ may be explained due to the
Table 2. Milk precipitation by various chemical treatments using the transmittance $(\%)$ and coagulation

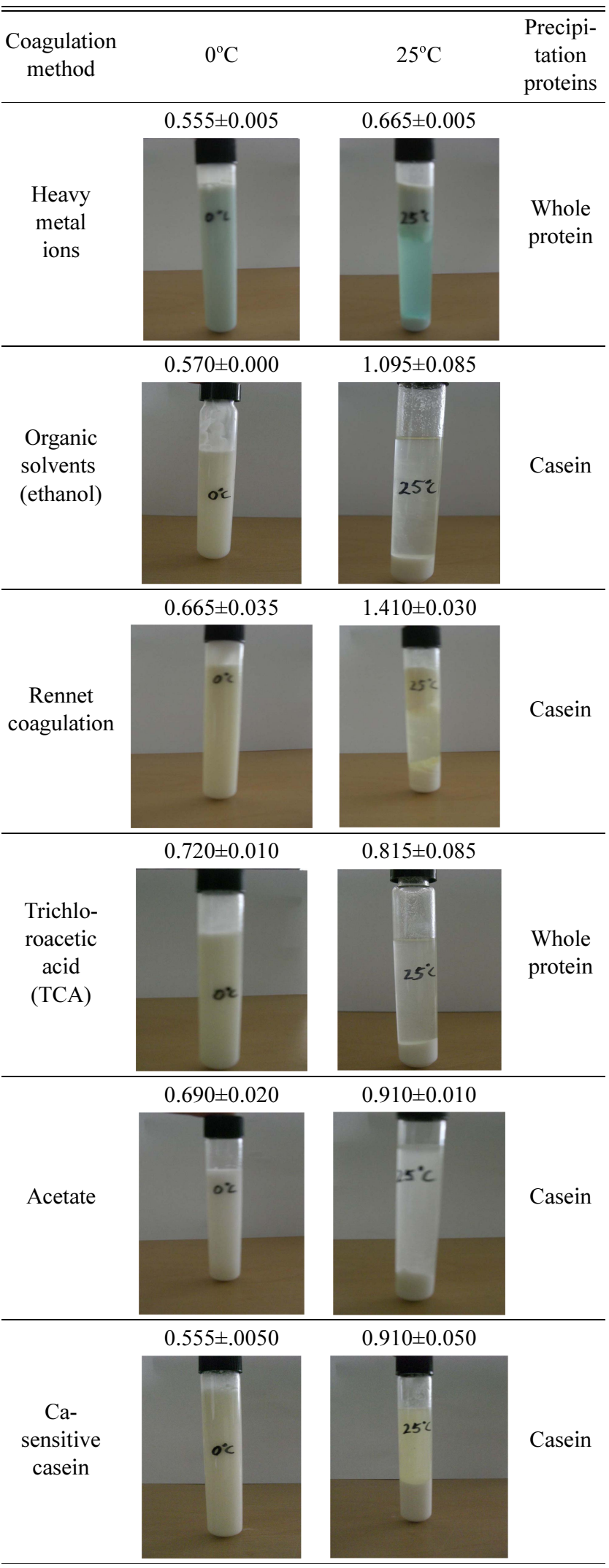

coagulated casein particle precipitation during measurement by results of the soluble phase increase. 
According to O'Connell et al. (2001), in ethanol treatment, the hydrodynamic radius and gyration of casein micelle at low temperature is decreased involoving no coagulation as ours. The reason that acetate treatment coagulation did not occur at $0^{\circ} \mathrm{C}$ could be related to $\mathrm{pK}$ dissociation value which could not arrive till isoelectric point of casein in spite of environmental $\mathrm{pH}$ 4.6. TCA treatment at $0^{\circ} \mathrm{C}$ did not provoke lateral change in solubility leading to no coagulation. For the precipitation of calcium chloride in cheese solution, the coagulation did not
Table 3. Effect of $\mathrm{Ca}$ and $\mathrm{Na}$ ions on the precipitation at $4^{\circ} \mathrm{C}$ by visual clotting time observation (h)

\begin{tabular}{lccc}
\hline \hline & Control & $\mathrm{NaCl}$ & $\mathrm{CaCl}_{2}$ \\
\hline Heavy metal ion & - & - & - \\
Organic solvent & - & - & 48 \\
Rennet & - & - & 72 \\
TCA & - & 48 & 72 \\
Isoelectric point & - & - & - \\
Ca-sensitive casein & - & - & - \\
\hline
\end{tabular}

-: no coagulation, Control : no $\mathrm{CaCl}_{2}$ and $\mathrm{NaCl}$ addition.

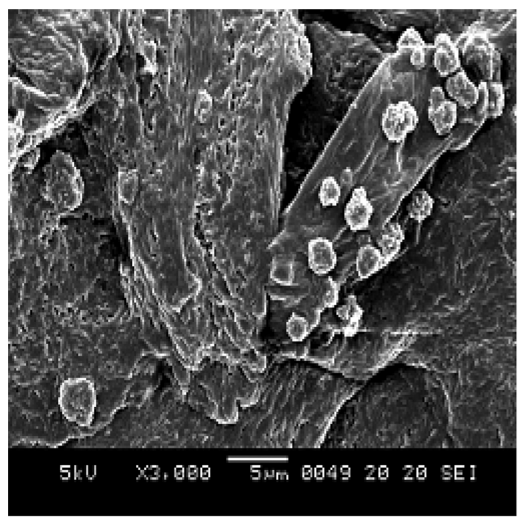

(a) Organic solvents

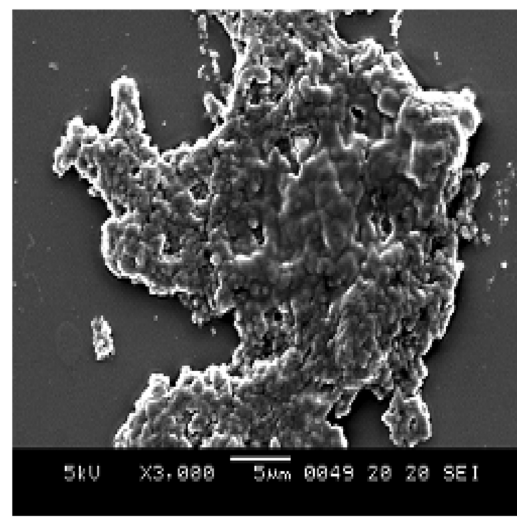

(c) Trichloroacetic acid

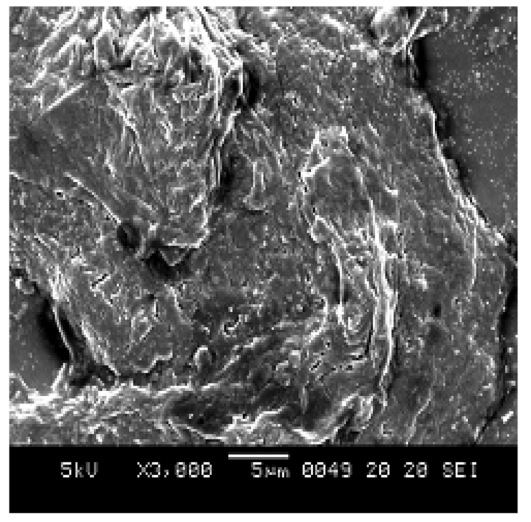

(e) Heavy metal

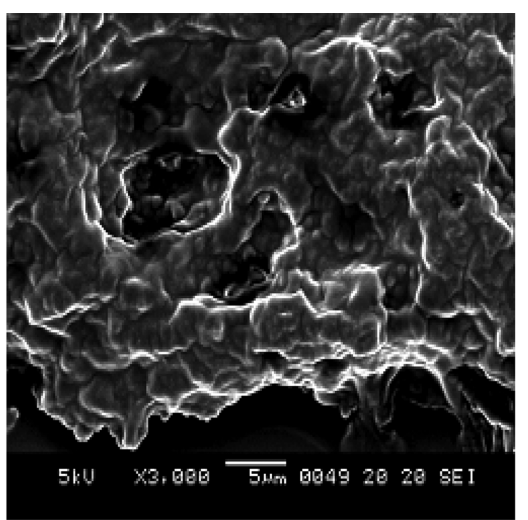

(b) Isoelectric point

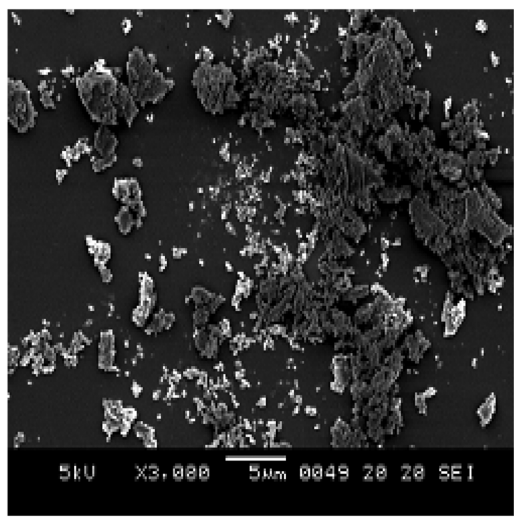

(d) Ca-sensitive casein

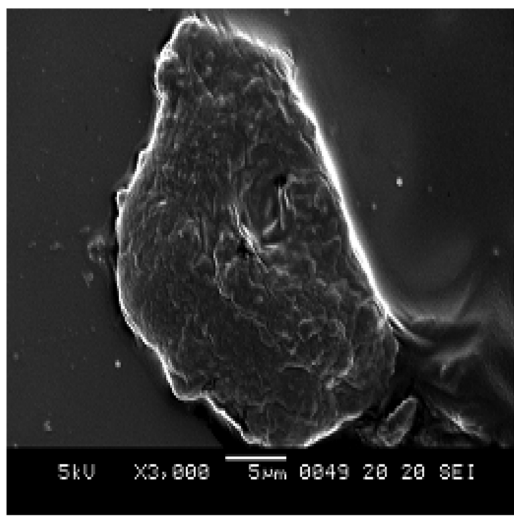

(f) Rennet

Fig. 2. Scanning electron microscope of precipitate according to precipitation conditions at $25^{\circ} \mathrm{C}$. After the precipitation treatment at $25^{\circ} \mathrm{C}$, samples were observed by SEM. The scale bar represents $5 \mu \mathrm{m}$. 
occur due to structural alteration at binding site at low temperature. Even with $\mathrm{Cu}^{2+}$ treatment no coagulation may be due to not change protein solubility in spite of its presence. In the case of rennet coagulation, similar results were found by Bansal et al. (2008) who have indicated that aggregation of casein micelles at $10^{\circ} \mathrm{C}$ was significantly slower by laser-light scattering particle size analysis.

These observations in all treatments at $0^{\circ} \mathrm{C}$ were consistent with previous works that casein micelle is more stable and smaller in size due to release of $\mathrm{Ca}^{2+}$ and â-casein solubilization in soluble phase (Alais, 1974; Walstra and Jenness, 1984; Jablonka and Munro, 1985). Therefore whatever coagulation factors were treated, it was difficult to coagulate it at low temperature.

On the contrary, coagulation of rennet casein micelles and gel firmness increases by addition of soluble $\mathrm{Ca}^{2+}$ in milk above $25^{\circ} \mathrm{C}$ (Green and Marshall 1977; Dalgleish 1983; Mehaia and Cheryan 1983). To verify $\mathrm{Ca}$ as well as $\mathrm{Na}$ ions effect at $4^{\circ} \mathrm{C}$, these ions were added to each milk which were treated by various coagulation factors. These results are represented in Table 3.

No coagulation for control was occurred regardless of time. After $1 \mathrm{M} \mathrm{CaCl}_{2}$ addition, the coagulation was observed at $48 \mathrm{~h}, 72 \mathrm{~h}$ and $72 \mathrm{~h}$ for ethanol, rennet and TCA treatment, respectively. These observations at low temperature may be related to micelle structure change allowing to increase hydrophobic interaction by recovering $\mathrm{Ca}^{2+}$ activity upon addition of $\mathrm{Ca}^{2+}$ (Bansal et al., 2008).

In the case of $\mathrm{NaCl}$ effect, there were no particular observations except for TCA treatment at $48 \mathrm{~h}$. This coagulation could be a result of increased ionic strength of milk by TCA despite the fact that $\mathrm{NaCl}$ addition increases solubilization due to shift of $\mathrm{Ca}$ ion into soluble phase replacing $\mathrm{Ca}$ ion leading to increased coagulation time (Sbodio et al., 2006).

Thus, this low temperature technique makes possible the fabricate of precheese powder prior to the second stage of coagulation.

\section{Micellar microstructure observation by SEM}

Microscopic observation after each treatment for coagulation or precipitation at $25^{\circ} \mathrm{C}$ by SEM has performed to verify their microstructure difference (Fig. 2).

For ethanol treatment, the precipitate presented fibrous bundle with protein and also presented the crystals that seemed to be $\mathrm{Ca}^{2+}$-compounds because these types of compounds are not well soluble in ethanol (Fig. 2-a).
There was continuous uneven tendance on surface with coagulum-collegate in the case of isoelectric point (Fig. 2-b). It seemed that TCA precipitate had also similar tendency of fusioned structured as well as a basically isoelectric point which presented flat surface and size of precipitate was indicated more smaller than isoelectric point precipitate (Fig. 2-c).

On the other hand, the precipitate of Ca-sensitive casein presented a coarse and small structure as compared to the other precipitates (Fig. 2-d). It can probably come from the difference of coagulation mechanism in protein structure which means that the casein has Ca-binding sites. Thus at low temperature, the $\mathrm{Ca}$ ion could not approach to Ca-binding sites (Fig. 2-d) but for precipitates by $\mathrm{Cu}^{2+}$ the grainy homogeneous dispersion of structure seemed to be like compact paste and hard structure (Fig. 2-e).

Finally, the precipitate by renneting showed homogeneous shrinkage and soluble phase but probably it might be syeneresis each other (Fig. 2-f).

\section{Application in cheese fabrication using precheese powder by the low temperature raw milk rennet- ing}

To make the precheese powder, the rennet coagulation method was applied at low temperature for cheese fabrication. The concentrated raw milk should be cooled till $0^{\circ} \mathrm{C}$ before renneting and renneted before the first reaction. The renneted milk was sent directly to cyclone (110 to $120^{\circ} \mathrm{C}$ ) before attaining the second reaction (coagulation).

The temperature of concentrated milk is also very important because the milk should not start to coagulate. The initial temperature should be far from drying temperature so that it can not coagulate during drying.

This application was applied in the precheese powder

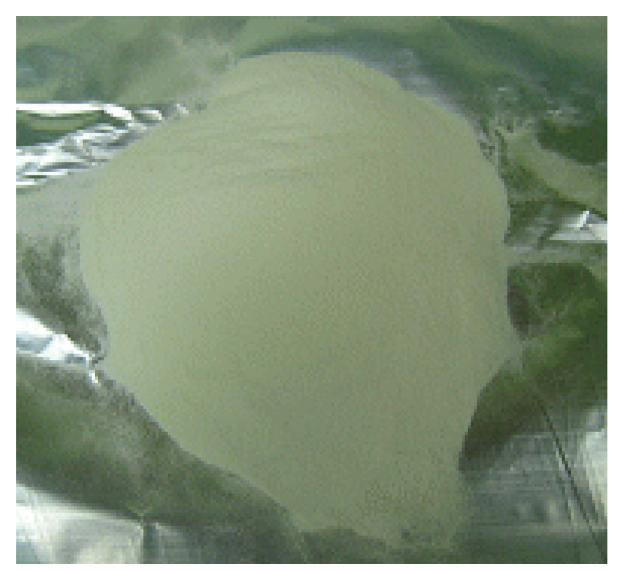

Fig. 3. General appearance of precheee powder. 
for cheese fabrication. General appearance of precheese powder and Camembert cheese from the precheese powder were represented in Fig. 3 and Fig. 4(a). This indicates the general appearance of the Camembert cheese from raw milk (Fig 4-b) and commercial product (Fig 4c), showing the possibility of this application to the precheese powder in food industries as a food additives.

In general, the syneresis for cheese fabrication is necessary to have curd after rennet treatment but the disavan-

(a)

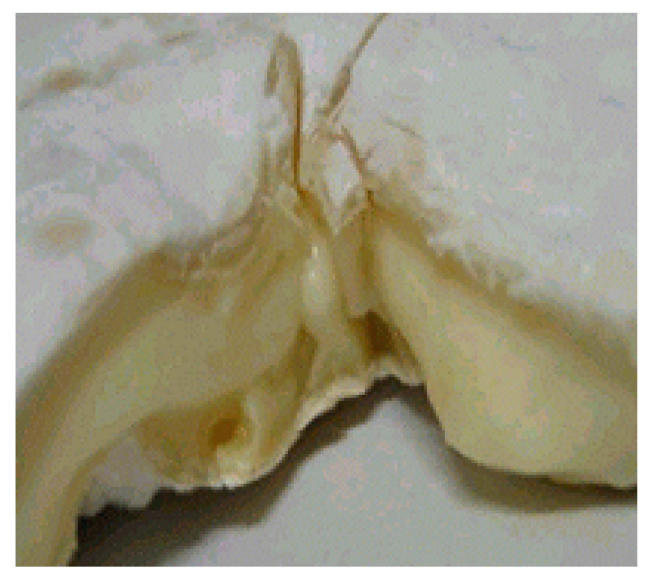

(b)

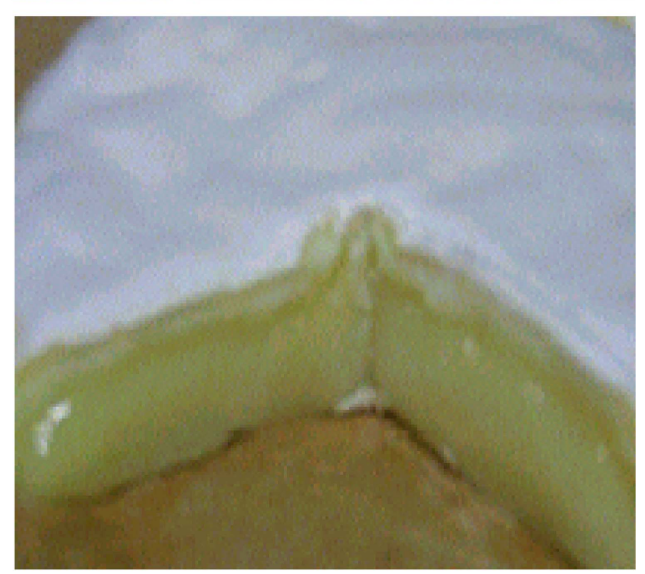

(c)

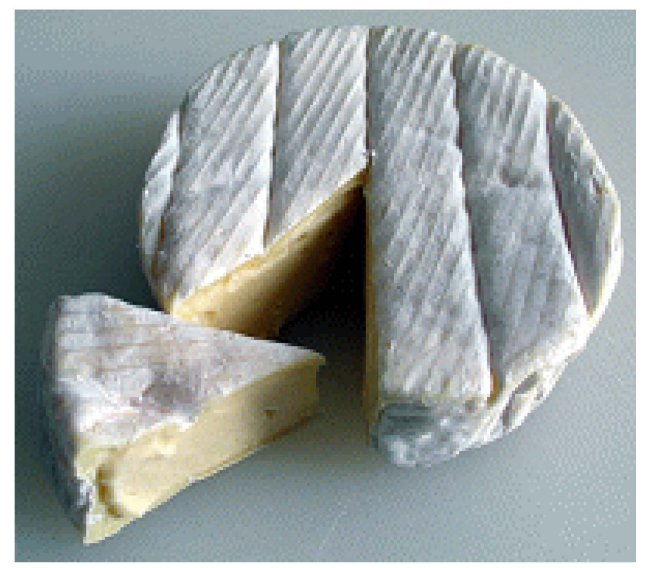

Fig. 4. General appearance of Camembert cheese from precheese powder (a) and raw milk (b). Image (c) is a commercial Camembert cheese appearance.

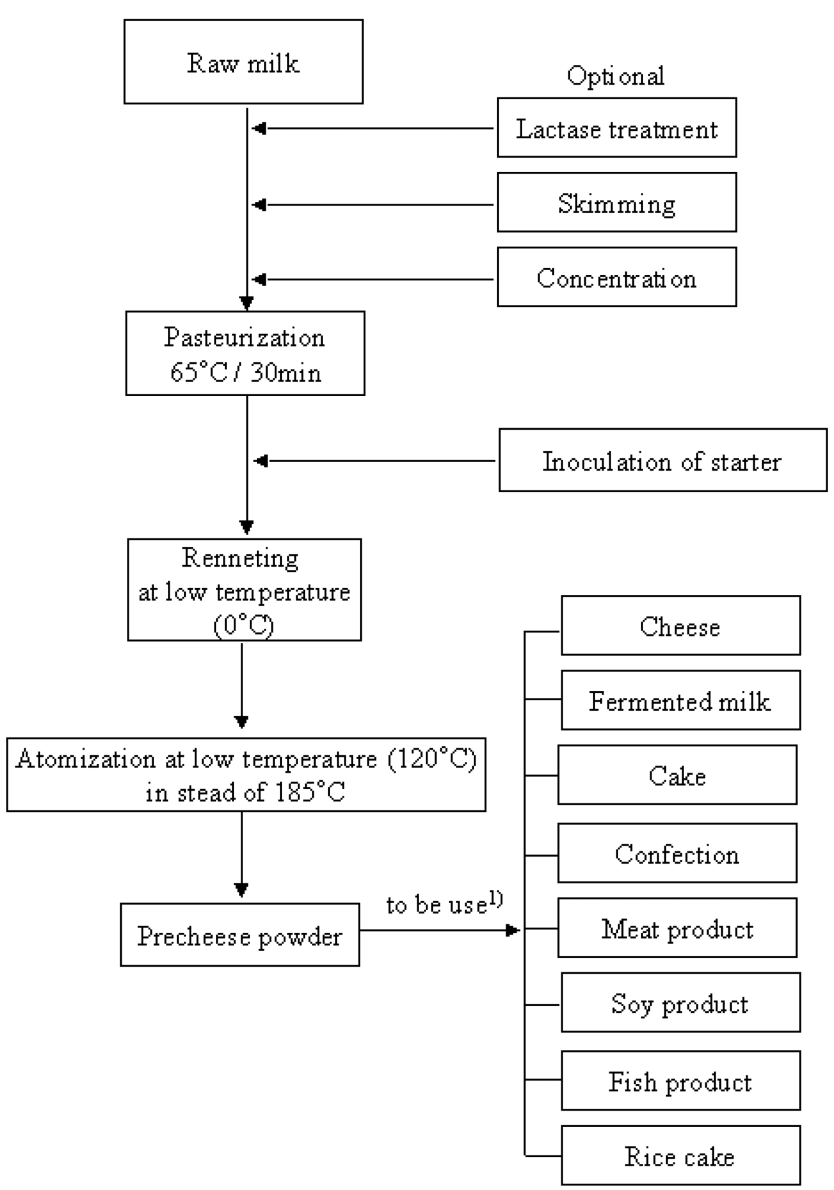

Fig. 5. Schematic representation of applicability of precheese powder in food technologies. 1) To be use this precheese powder, it should solubilize in cold water and mix with the main ingredient at $0^{\circ} \mathrm{C}$ and then treat heating above $20^{\circ} \mathrm{C}$ to obtain paste with good rheology of products.

tage is that the soluble proteins and components in whey are eliminated during syneresis.

The low temperature coagulation in this study do not need this syneresis.

From these results, we can assume that it has also the amelioration of elevated palatability, nutritive values and rheology in the application of cheese, yogurt, meat, fish, soybean, bake, confectionary, rice cake and noodle (Fig. 5).

This technique could bring the economical potency by using diverse applications in whole food industry and could also be used to effectively prevent the surplus milk accumulation by conversion into precheese powder rather than milk powder. However the further studies of diverse processing factors will be required to apply in food industry.

\section{References}

1. Alais, C. (1974) Science du lait et principes des techniques 
laitières. 3th ed. sepec, Paris.

2. Ausar, S. F., Bianco, I. D., Baini, R. G., Castagna, L. F., and Modesti, N. M., Landa, C. A., and Beltramo, D. M. (2001) Characterization of Casein Micelle Precipitation by Chitosans. J. Dairy Sci. 84, 361-369.

3. Bansal, N., Fox, R. F., and McSweeney, P. L. H. (2008) Factors that affect the aggregation of rennet-altered casein micelles at low temperatures. Int. J. Dairy Tech. 61, 56-61.

4. Bansal, N., Fox, R. F., and McSweeney, P. L. H. (2007) Aggregation of Rennet-Altered Casein Micelles at Low Temperatures. J. Agric. Food Chem. 55, 3120-3126.

5. Boutrou, R., Gaucheron, F., Poit, M., Michel, F., Maubois, J. L., and Léonil, J. (1999) Changes in the composition of juice expressed from Camembert cheese during ripening. Lait. 79, 503-513.

6. Bringe, N. A. and Kinsella, J. E. (1987) Forces involved in the enzymatic and the acidic coagulation of casein micelles. in Developments in Food Protein. B. J. F. Hudson, ed. Elsevier Applied Science, London, UK, pp. 159-194.

7. Brinkhuis, J. and Payens, T. A. J. (1984) The influence of temperature on the flocculation rate of renneted casein micelles. Biophys. Chem. 19, 75-81.

8. Chang, O. K., Humbert, G., Gaillard, J. L., and Lee, B. O. (2006) Characterization of Equine Milk and Cheese Making. Korean J. Food Sci. Ani. Resour. 26, 368-374.

9. Dalgleish, D. G. (1983) Coagulation of renneted casein micelles: dependence on temperature, calcium ion concentration and ionic strength. J. Dairy Res. 50, 331-340.

10. Daviau, C., Famelart, M. H., Pierre, A., Goudédranche, H., and Maubois, J. L. (2000) Rennet coagulation of skim milk and curd drainage: Effect of $\mathrm{pH}$, casein concentration, ionic strength and heat treatment. Lait 80, 397-415.

11. de Kruif, C. G. and Holt, C. (2003) Casein micelle structure, functions and interactions. In Advanced Dairy Chemistry, 3rd edn, Fox, P. F. and McSweeney, P. L. H. eds., Kluwer Academic/Plenum Publishers, NY. pp. 233-276.

12. Fritsch, R. J., Martens, F., and Belitz, H. D. (1992) Monitoring Cheddar cheese ripening by chemical indices of proteolysis 1. Determination of free glutamic acid, soluble nitrogen, and liberated amino groups. Zeitschrift für Lebensmitteluntersuchung und -Forschung A 194, 330-336.

13. Green, M. L. and Marshall, R. J. (1977) The acceleration by cationic materials of the coagulation of casein micelles by rennet. J. Dairy Res. 44, 521-531.

14. Hanboul Foodcheepia. Co. (2005) Manufacture of precheese powder and food made from precheese powder. Korea Patent 0489662.

15. Holt, C. and Horne, D. S. (1996) The hairy casein micelle: evolution of the concept and its implications for dairy technology. Neth. Milk Dairy J. 50, 85-111.

16. Holt, C. (1992) Structure and stability of bovine casein micelles. In Advances in Protein Chemistry. Afinsen, C. B., Sall, J. D. E. D., Richards, F. K., and Eisenberg, D. S. ed., Acad. Press, New York, NY, pp. 63-151.

17. Horne, D. S. and Banks, J. M. (2004) Rennet-induced coagulation of milk. In Cheese: Chemistry, Physics and Microbi- ology, 3rd ed, Vol. 1, Fox, P. F., McSweeney, P. L. H., Cogan, T. M., and Guinee, T. P. eds., Chapman and Hall, London, pp. 47-70.

18. Horne, D. S. (2002) Casein structure, self-assembly and gelation. Curr. Opin. Colloid In. 7, 456-461.

19. Horne, D. S. (1998) Casein Interactions: casting light on the black boxes, the structure in dairy products. Int. Dairy J. 8, 171-177.

20. Jablonka, M. S. and Munro, P. A. (1985) Particle size distribution and calcium content of batchprecipitated acid casein curd: effect of precipitation temperature and $\mathrm{pH}, J$. Dairy Res. 52, 419-428.

21. Korean Biochemistry Society. (1997) Experimental Biochemistry. Ed. Tamgudang (in Korean).

22. Ko, Z. S., Kwak, H. S., Kim, Y. H., Kim, Z. W., Nam, M. S., Park, S. Y., Bae, I. H., Baik, S. C., Yun, S. S., Lee, B. O., In, Y. M., Lim, Z. W., Chang, O. K., Jeong, J. N., Choi, Y. I., Hoe, K. T., Hong, Y. H. and Hwang, J. H. (2002) Milk Food Processing. Sun Jin Moon Wha Sa (in Korean).

23. Lee, B. O. (1981) Etude biochimique de la fonte des fromages. Ph. D. thesis, Université de Nancy-1., Nancy, France.

24. Lucey, J. A. and Singh, H. (2003) Acid coagulation of milk. In Advanced Dairy Chemistry, 3rd ed, Fox, P. F. and McSweeney, P. L. H. eds., Kluwer Academic/Plenum Publishers, NY. pp. 1000-1021.

25. Manso, M. A., Léonil, J., Piot, M., and Gagnaire, V. (2005) Isolation and characteri-sation of a Lactobacillus helveticus ITG LH1 peptidase-rich sub-proteome. Int. J. Food Microbiol. 105, 119-129.

26. Mehaia, M. A. and Cheryan, M. (1983) The secondary phase of milk coagulation. Effect of calcium, $\mathrm{pH}$ and temperature on clotting activity. Milchwissenschaft. 38, 137-140.

27. Ministère de l'Agriculture. Direction des Services Vétérinaire. (1973) Contrôle de la qualité des produits laitiers. Tome I. Analyse physique et chimique.

28. Molimard, P., Vassal, L., Bouvier, I., and Spinnler, H. E. (1995) Suivi de croissance de Penicillium camemberti et Geotrichum candidum en culture pure et en association au cours de l'affinage de fromages expérimentaux à pâte molle de type camembert. Lait 75, 3-16.

29. Nàjera, A. I., de Renobales, M., and Barron, L. J. R. (2003). Effects of $\mathrm{pH}$, temperature, $\mathrm{CaCl}_{2}$ and enzyme concentrations on the rennet-clotting properties of milk: A multifactorial study. Food Chem. 80, 345-352.

30. Noomen, A. (1977) A rapid method for the estimation of dissolved and undissolved nitrogen compound in cheese. Neth. Milk Dairy J. 31, 163-176.

31. O'Connell, J. E. and Fox, R. F. (2000) The stage coagulation of milk proteins in the minimum of the heat coagulation time $\mathrm{pH}$ profile of milk : effect of casein micelle size. J. Dairy Sci. 83, 378-386.

32. O’Connell, J. E., Kelly, A. L., Auty, M. A. E., Fox, R. F., and de Kruif, K. G. (2001) Ethanol-dependent heat-induced dissociation of casein micelles. J. Agric. Food Chem. 49, 44204423.

33. Rasic J. L. and Kurmann J. A. (1978) Yoghurt. Scientific 
Grounds, Technology, Manufacture and Preparations. Teohnical Dairy Publishing House, Copenhagen, pp. 90-97.

34. Robinson, R. K. (1986) Modern Dairy Technology. Volume 1. Advances in Milk Processing. Elsevier Applied Science Publisher, London and NY, pp. 317.

35. Sbodio, O. A., Terecro, E. J., Coutaz, R., and Revelli, G. R. (2006). Effect of rennet and sodium chloride concentration on milk coagulation properties. Cienc. Technol. Aliment 5, 182-188.

36. Schlesser, J. E., Schmidt, S. J., and Speckman, R. (1992) Characterization of chemical and physical changes in cam- embert cheese during ripening. J Dairy Sci. 75, 1753-1760.

37. Schmidt, D. G.. (1982) Electron microscopy of milk and milk products: problems and possibilities. Food Microstruct. 1, 151-165.

38. Walstra, P. (1999) Casein sub-micelles: do they exist? Int. Dairy J. 9, 189-192.

39. Walstra, P. and Jenness, R. (1984) Dairy Chemistry and Physics. John Wiley and Sons, New York.

(Received 2010.2.2/Revised 1st 2010.4.10, 2nd 2010.5.14/

Accepted 2010.5.18) 